\title{
"Do We Have Any Men to Follow in Her Footsteps?": The Black Southern Press and the Fight for Teacher Salary Equalization
}

\section{Thomas Aiello}

The black southern press was an entity dominated by male editors and entrepreneurs. The effort to equalize teacher pay, one of the core fights for rights in the South, and the principal effort at gendered race advocacy during the World War II era, was led in large measure by black women. While both the fight for salary equalization and the survival of the black press depended upon segregation to maintain their survival, those newspapers were entities dominated by men advocating for equal salaries in a profession dominated by women, and the gendered nature of their coverage shaped knowledge of the fight within the black community.

In 1938, Walter Mills, a school principal in Anne Arundel County, Maryland, sued his school system in federal district court with the help of the NAACP, alleging that his salary and that of the teachers in his charge was far less than those of white teachers, which violated state laws mandating separate but equal education. He had watched in 1936 and 1937 as similar efforts in Montgomery and Calvert counties had ended in salary equalization without definitive rulings and he wanted an official mandate. ${ }^{1}$

Later that year, on the other side of the South, B. M. Jackson founded a newspaper, the Galveston Examiner, on the island city just off the Texas coast. It would survive only two years, typical of small southern startups without the resources or readership to maintain long

Thomas Aiello (taiello@valdosta.edu) is Associate Professor of History and African American studies at Valdosta State University. He is the author of The Battle for the Souls of Black Folk: W.E.B. Du Bois, Booker T. Washington, and the Debate That Shaped the Course of Civil Rights, and Jim Crow's Last Stand: Nonunanimous Criminal Jury Verdicts in Louisiana as well as several other books.

${ }^{1}$ Mills v. Board of Education of Anne Arundel County, 30 F. Supp. 245 (D. Md. 1939); Ada F. Coleman, "The Salary Equalization Movement," Journal of Negro Education 16, no. 2 (Spring 1947), 236; Hannah Jopling, Life in a Black Community: Striving for Equal Citizenship in Annapolis, Maryland, 1902-1952 (Lanham, MD: Lexington Books, 2015), 129-43; and Andor Skotnes, A New Deal for All?: Race and Class Struggles in Depression-Era Baltimore (Durham, NC: Duke University Press, 2013), 293-98. 
publication histories. $^{2}$ In December 1939, however, Jackson's paper reported the federal court ruling in Maryland on the front page. The Anne Arundel County school board had fixed salaries at different levels based solely on race, the Examiner explained, and the decision mandated one salary schedule for public school teachers regardless of race. Of course, as Galveston and other southern regions discovered, the Anne Arundel County ruling was a beginning, not an end, in a fight for pay equalization that would continue for years. Still, the Examiner was hopeful. ${ }^{3}$

Coverage of the suit was ubiquitous in the nearby Baltimore AfroAmerican, and its pages have provided strong source material for historians of the effort to equalize teacher pay. That effort, however, was one of the core rights fights in the South and witnessed almost all of its post-Maryland outgrowths south of the state's border, making the region's smaller, less recognized black newspapers vital to interpreting the movement for their readers. ${ }^{4}$ The Anne Arundel suit was led by a male principal, but the salary equalization fight was also the principal effort at gendered race advocacy during the World War II era, as the bulk of black teachers were women. It was a generation prior to the slow trickle of school desegregation, so various advocacy groups, including the NAACP, worked for equality within the segregated system, making the case that black teachers did the same work as white teachers and, therefore, deserved equal salaries. It was a fight that witnessed successes and failures in the late 1930s and 1940s, and it was a fight that the black southern press was uniquely suited to cover. These newspapers were in communities where strikes and lawsuits commenced, and they too were struggling for equality within a business that fundamentally depended upon segregation. They were, however, entities dominated by men advocating for salary equalization in a profession dominated by women, a problematic advocacy that often created a paternalistic proxy fight that played on common tropes of dependent femininity. Black southern newspapers often get short historical shrift because they were short-lived, and so few were saved. But they held significant sway with the black population in their cities and states, and they served as the conduits of local information about teacher salary equalization fights across the region, encouraging new

${ }^{2}$ Armistead Scott Pride, "A Register and History of Negro Newspapers in the United States: 1827-1950" (PhD diss., Northwestern University, 1950), 363; and "To Storm-Swept City," New York Times, Sept. 11, 1900, 1.

3 "Federal Court Orders Equal Teachers Pay," Galveston Examiner, Dec. 2, $1939,1$.

4 "Mrs. Williams Appointed To School Board," Baltimore Afro-American, June 24, 1939, 1, 2; and Haywood Farrar, The Baltimore Afro-American, 1892-1950 (Westport, CT: Greenwood Press, 1998), 34. 
outgrowths of those fights as a result of syndicated coverage throughout the South and reversing traditional gender roles by acting as male stewards for female leaders and activists.

To be sure, plenty of male teachers existed, some of whom worked diligently for salary equalization, and a number of women were journalists and editors, even in the South. And the vast majority of black southern teachers and black southern journalists, regardless of gender, believed that black teachers deserved the same salaries as their white counterparts. But when those majorities matched up, when black male journalists in the South advocated for and reported on teacher salary equalization efforts spearheaded by women, that mediation came with paternalistic assumptions and language that often diminished the pioneering roles female teachers played in those fights.

\section{Black Women and Public Education in the South}

Public education in the South was slow in coming, but upon its arrival in the nineteenth century, what began as yet another male-dominated endeavor evolved into a female profession. In North Carolina in 1884, for example, only 731 of the state's 2,231 black teachers were women. By 1900, just as many women were teaching as men, and in the coming decades, the profession would fall predominantly under the purview of African American women, as would its white counterpart. In 1920, the total teaching force was 85 percent female, in 1930 it was 81 percent. That number fell somewhat in the 1930s as a masculine backlash against married women working served as a scapegoat for the Depression, somewhat diminishing the female teaching load; even with that hindrance, the profession remained 78 percent female. With men being drafted into the military during World War II, the percentage of female teachers rose precipitously again. Not only were the numbers of black teachers growing, so too were their credentials. The number of black teachers in southern states with bachelor's degrees rose from 12 percent in 1930 to 72 percent in $1950.5^{5}$ This was aided by the fact that economic necessity and philosophical outlook kept black education from following the white trend of single-sex education, allowing black women to take advantage of what education developed post-Reconstruction to qualify themselves as teachers. As

${ }^{5}$ Susan Ware, Holding Their Own: American Women in the 1930s (Boston: Twayne, 1982), 72; John A. Kirk, “The NAACP Campaign for Teachers' Salary Equalization: African American Women Educators and the Early Civil Rights Struggle," Journal of African American History 94, no. 4 (Fall 2009), 534-35; and Scott Baker, "Pedagogies of Protest: African American Teachers and the Civil Rights Movement," Teachers College Record 113, no. 12 (Dec. 2011), 2783. 
historian Glenda Gilmore explains, black southerners emerging from the slave period valued "strength, initiative, and practicality among black women," and the "system of higher education they constructed reflected those ideals." 6 And until 1890, North Carolina paid those teachers an ostensibly equal wage, though black teachers were asked to do so much more, often responsible for classrooms with pupils ranging in age from five to nineteen. As the teaching force became more female, however, and white Redeemer politicians found more and more clever ways to punish former slaves simply for not being slaves, public school pay scales separated further and further. ${ }^{7}$

In the seventeen states and District of Columbia that mandated segregated public education, the average salary for black teachers in 1930 was roughly half that of white teachers. That average rose to 65 percent by the end of World War II and 85 percent by 1950. "It was black men's exclusion from the political sphere," explains Gilmore, "not black women's willingness to work for low wages, that caused African American teachers to be poorly compensated." ${ }^{8}$ Thus it was a fight, despite the early role of Walter Mills, that was led by courageous black women. Activist Septima Clark described her efforts at salary equalization as her "first effort in a social action challenging the status quo." 9 Likewise, influential South Carolina NAACP secretary Modjeska Simkins began her most prolific period of activism in the teachers' salary movement. In addition to women's activism, women were also the teachers, and thus the plaintiffs-Mills and several others excepted-in equalization lawsuits throughout the South. As historian John A. Kirk notes, the gendered equalization effort was coordinated by the NAACP, thus "from grassroots African American women's activism in teachers' salary equalization suits to Ella Baker's role in the NAACP's national office, African American women played a vital part in the dramatic rise in NAACP membership and activism in the 1940s." 10

Exemplary of such a statement is Lulu B. White, executive secretary of Houston's NAACP chapter, who, while not a plaintiff in the city's teacher salary equalization case, was "intimately involved" in it nonetheless. After victory, White "used every possible means of

${ }^{6}$ Glenda Elizabeth Gilmore, Gender \& Jim Crow: Women and the Politics of White Supremacy in North Carolina, 1896-1920 (Chapel Hill: University of North Carolina Press, 1996), 33.

${ }^{7}$ Ibid., 33-37.

${ }^{8}$ Ibid., 157.

${ }^{9}$ Kirk, "The NAACP Campaign for Teachers' Salary Equalization," 533.

${ }^{10}$ Kirk, "The NAACP Campaign for Teachers' Salary Equalization," 533, 53536; and Robert A. Margo, Race and Schooling in the South, 1880-1950: An Economic History (Chicago: University of Chicago Press, 1990), 52-67. 
communication - newspapers, pamphlets, lectures, rallies- to inform teachers of the role" of the NAACP. ${ }^{11}$ Those newspapers were, in Houston and throughout the South, largely dominated by men, thus reversing gender norms by putting male-dominated endeavors at the service of publicizing the efforts of a rights fight led and dominated by women. Many studies have detailed salary equalization lawsuits and activism, with many different trajectories. This effort, however, is concerned most specifically with journalistic mediation, with black southern newspapers reporting on salary equalization as one of White's "means of communication," and the consequences of that deviation from social norms for black southern rights fights in the postwar era. ${ }^{12}$

African American women began carving a significant place for themselves within their own community following emancipation, though the pressures of poverty and a male-dominated black culture made significant gains difficult. As Hazel Carby has argued about the nineteenth century, black women, in both self-definition and popular understanding, became contradictory objects upon attempting to enter the public sphere-both active adherents to "the dominant discourse of white women's politics" and social outsiders on the opposite side of the cultural color line. In this environment, black women activists and writers had to construct a "discourse of black womanhood," because the domestic and literary ideals that shaped the late nineteenth-century cultural definition of womanhood actually created a definition of white womanhood. ${ }^{13}$

Paula Giddings argues dually that racism and sexism, though fundamentally different, stem from the same "economic, social, and psychological" forces, and that in the struggle for equality, black women often compromised their feminist leanings for the sake of African American struggles and sometimes compromised their African American identities in order to ensure that the state of black

\footnotetext{
${ }^{11}$ Kirk, "The NAACP Campaign for Teachers' Salary Equalization," 535.

${ }^{12}$ For examples of earlier equalization studies, see Charles H. Thompson, "Progress in the Elimination of Discrimination in White and Negro Teachers' Salaries," Journal of Negro Education 9, no. 1 (Jan. 1940), 1-4; Bruce Beezer, "Black Teachers' Salaries and the Federal Courts before Brown v. Board of Education: One Beginning for Equality," Journal of Negro Education 55, no. 2 (Spring 1986), 200-13; Scott Baker, "Testing Equality: The National Teacher Examination and the NAACP's Legal Campaign to Equalize Teachers' Salaries in the South, 19361963," History of Education Quarterly 35, no. 1 (Spring 1995), 49-64; and Mark V. Tushnet, Making Civil Rights Law: Thurgood Marshall and the Supreme Court, 19361961 (New York: Oxford University Press, 1994), 116-21.

${ }^{13}$ Hazel V. Carby, Reconstructing Womanhood: The Emergence of the Afro-American Woman Novelist (New York: Oxford University Press, 1987); and Karen Anderson, Changing Woman: A History of Racial Ethnic Women in Modern America (New York: Oxford University Press, 1996).
} 
womanhood remained viable. ${ }^{14}$ Jacqueline Jones sees that a continuously shifting economic climate from antebellum slavery to the present often marginalized and subjugated the working urban and rural poor-black and white, male and female-but African American women, already firmly in the grips of a cultural double bind, suffered unique (and often greater) hardship throughout the nation's various social, political, and economic manifestations. In the public workforce, "black women" often became relegated to "black women's work," a further distinction in gendered employment roles historians often overlook. In their private lives, women served as devoted mothers and wives as well as general facilitators of community spirit within black society. This propagation of dual roles within dual roles and double binds within double binds created an economic situation almost impossible to improve, even without the machinations of the US economy and the often turbulent transition from slavery to freedom to Jim Crow to general economic inferiority.

Following World War I, women struggled to escape domestic service and develop their viability as a legitimate segment of the workforce with a wage almost equal to that of their male counterparts. Again, unlike white women, African Americans had no choice but wage labor, and the development of "white women's jobs," such as secretarial and sales work, only limited black women's choices. The Depression of the 1930s damaged an already hurting black population, forcing black women to shoulder even more of the heavy burden. Through the work they were able to find, however, African American women unionized, took a growing interest in politics, and developed a sense of black consciousness. With the early development of civil and women's rights issues between World War II and Brown, Jones's black women largely eschewed Giddings's compromises and sided squarely with their own black identity and the principal issues of civil rights. The necessity of their labor, their obvious inequality with white women, and their exponential economic and motherly influence on the black family and community made this choice relatively simple. ${ }^{15}$

Perhaps even more relevant is the work of Patricia Hill Collins, who describes prewar black female domestic workers as "outsiderswithin," with access to white spaces denied to black men yet still marginalized and exploited in those spaces. White school boards in the prewar South created a similar situation for the bulk of that female

\footnotetext{
${ }^{14}$ Paula Giddings, When and Where I Enter: The Impact of Black Women on Race and Sex in America (New York: William Morrow, 1984).

${ }^{15}$ Jacqueline Jones, Labor of Love, Labor of Sorrow: Black Women, Work, and the Family, from Slavery to the Present (New York: Basic Books, 1985).
} 
educational workforce, leading them to activism that reclaimed "black feminist intellectual traditions." In their fight for salary equalization, their courage to fight against those intersectional binds of race and gender, female teachers were claiming, in the words of Collins, "the power to name one's own reality." 16 That intersectional act of claiming their own reality was the most substantial effort of the teachers fighting for salary equalization, as a group of black women worked through the constraints of an ideological masculinity inherent in black rights activism and a narrative masculinity inherent in black journalism to make a race equity claim that would ultimately benefit the whole of the black middle class. ${ }^{17}$

\section{Black Men and Journalism in the South}

While black education evolved simultaneously with the gendering of that space, the black press had long been dominated by men, which remained a relative constant through its evolution. Robert Sengstacke Abbott and his nephew John Sengstacke founded and controlled the Chicago Defender. James H. Anderson founded the New York Amsterdam News. Robert L. Vann dominated the Pittsburgh Courier, P. B. Young the Norfolk Journal and Guide. In the Deep South, where the bulk of the teacher salary fight would develop, the growth of newspapers was facilitated by brothers W. A. and C. A. Scott, who founded the Atlanta Daily World and the Scott Newspaper Syndicate (SNS), which controlled well over two hundred newspapers in its lifetime.

W. A. Scott would, with the help of C. A., begin his small, fourpage weekly in 1928. In 1930, the World became a semiweekly, and in January of the following year, Scott formed the Southern

\footnotetext{
${ }^{16}$ Patricia Hill Collins, Black Feminist Thought: Knowledge, Consciousness, and the Politics of Empowerment (New York: Routledge, 2000), 12.

${ }^{17}$ Ibid., 12, 17, 300; and Patricia Hill Collins, "Learning from the Outsider Within: The Sociological Significance of Black Feminist Thought," Social Problems 33, no. 6 (Dec. 1986), S14-S32. For more on intersectionality and its role in shaping black women's thought and action in relation to civil rights, see Michael Awkward, Negotiating Difference: Race, Gender and the Politics of Positionality (Chicago: University of Chicago Press, 1995); Elsa Barkley Brown, "What Has Happened Here? The Politics of Difference in Women's History and Feminist Politics," in We Specialize in the Wholly Impossible: A Reader in Black Women's History, ed. Darlene Clark Hine, Wilma King, and Linda Reed (New York: New York University Press, 1992), 39-56; Julia JordanZachery, "Am I a Black Woman or a Woman Who Is Black? A Few Thoughts on the Meaning of Intersectionality," Politics and Gender 3, no. 2 (June 2007), 254-63; Mari Matsuda, "Beside My Sister, Facing the Enemy: Legal Theory Out of Coalition," Stanford Law Review 43, no. 6 (July 1991), 1183-92; and Dara Z. Strolovitch, Affirmative Advocacy: Race, Class, and Gender in Interest Group Politics (Chicago: University of Chicago Press, 2007).
} 
Newspaper Syndicate. In March 1932, the World became a daily. When the Syndicate's reach began drifting beyond the bounds of the South in 1933 , W. A. Scott changed its name to the Scott Newspaper Syndicate. The following year, in February 1934, W. A. was murdered and his brother took over the company. ${ }^{18}$ At the time of his death, the Syndicate owned one daily, two semiweeklies, and printed more than fifty other weekly papers that blanketed the South and parts of the Midwest. The Scotts and their Atlanta Daily World did not own most of the papers they printed. Instead, local southerners and would-be journalists wrote articles and editorials about the local news in their area, generated advertisements for local businesses, and then sent that collected material to Atlanta, where SNS staff would lay out the material, add syndicated national news from the World and other Syndicate papers, print the finished product, and then send it back. It was a system that allowed almost anyone to become a journalist, and the bulk of those who took that opportunity were men. ${ }^{19}$ Those men, in turn, reported on teacher salary fights and became the de facto public advocates for women in a proxy fight for equalization. It was, to be sure, the kind of causal chain that could create legitimate problems of interpretation.

Such is not to say that the history of black southern journalism itself did not include women and did not have previous intersections with the teaching profession. Lucy J. Cochran, for example, began working at the Lexington Herald before starting her own Kentucky paper, the Lexington Record, and aligning it with Atlanta's SNS from 1934 to 1936 . Women had an important history in black southern journalism dating to the nineteenth century, feeding particularly from the boom in black newspapers in the 1890s. Of the forty-six female journalists in the last two decades of the nineteenth century that historian Gloria Wade-Gayles studied, more than half were from the South. The female journalists in Wade-Gayles's study came from all economic backgrounds. Ida Wells, originally from Mississippi but who more famously worked in Memphis, and Victoria Earle Matthews of Georgia, who worked at papers across the country, were both from impoverished backgrounds. Mary Church Terrell of Memphis and Josephine Turpin Washington, on the other end of that spectrum,

\footnotetext{
${ }^{18}$ Julius E. Thompson, Percy Greene and the Jackson Advocate: The Life and Times of a Radical Conservative Black Newspaperman, 1897-1977 (Jefferson, NC: McFarland, 1994), 25-26; "SNS Leader Speaks in Home Town," Atlanta Daily World, March 13, 1934, 1; "Death Claims Publisher of Chain Papers," New York Amsterdam News, Feb. 14, 1934, 1; Alton Hornsby Jr., "Georgia," in The Black Press in the South: 1865-1979, ed. Henry Lewis Suggs (Westport, CT: Greenwood Press, 1983), 127-30; and Allen Woodrow Jones, "Alabama," in The Black Press in the South, ed. Henry Lewis Suggs, 43.

${ }^{19}$ Tademy v. Scott, 68 F. Supp. 556 (N.D. Ga1945).
} 
were born into relative wealth. Still, when they joined the journalistic ranks, they made virtually no money. All of Wade-Gayles's subjects, Matthews excepted, worked as teachers simply to make ends meet. Black journalism in the South was as misogynistic a business as any other, with the same glass ceilings as its counterpart industries, but such did not make women any less crucial to the process. ${ }^{20}$

Women from outside the region also came down to cover civil rights efforts of various kinds, with perhaps the most famous arriving in the years after the teacher salary fight. Chicago's Ethel L. Payne, known as the "First Lady of the Black Press," worked for the Chicago Defender in the 1950s and 1960s and spent time in the South covering the civil rights movement, from the Montgomery Bus Boycott to the March on Washington. Still, northern reporters like Payne were tourists in the region, and editors like Cochran were the exception rather than the rule in a gendered business that coded journalism as a functionally male endeavor. ${ }^{21}$ In 1935, for example, Nathaniel N. Baker, a bellman for several different hotels in Pensacola, Florida, with only a high school education, founded the Pensacola Courier and edited it until the early 1950s, when his wife, Cora, took over. ${ }^{22}$ The Pensacola Courier, in the more traditionally conservative southern region of the Florida panhandle, was correspondingly reticent to directly attack white supremacists, but one of its most sustained fights was one common to much of the black South in the late 1930s and early 1940s: the equalization of teacher salaries. The equalization fight would be spearheaded by the NAACP, which, as Tomiko Brown-Nagin has explained, "perceived African American educators as being at once a core constituency of, and a political threat to, the association's agenda." The fight for equalizing teacher pay was important because of the fundamental injustice to black teachers and the ancillary demeaning of black children's education, but it would also help the NAACP "shore up its support among educators," who composed "a large

${ }^{20}$ Scott Newspaper Service [syndicating service], 1935, OBV136, Atlanta Daily World records, Stuart A. Rose Manuscript, Archives, and Rare Book Library, Emory University; and Gloria Wade-Gayles, "Black Women Journalists in the South, 18801905: An Approach to the Study of Black Women's History," Callaloo 11/13 (Feb.-Oct. 1981), 139-44, 147.

${ }^{21}$ For more on Payne, see James McGrath Morris, Eye on the Struggle: Ethel Payne, the First Lady of the Black Press (New York: HarperCollins, 2015).

${ }^{22}$ Pensacola City Directory, 1936 (Jacksonville, FL: R.L. Polk, 1936), 53; US Census, Sixteenth Census of the United States: 1940, Population Schedule, Sheet No. 3B, Pensacola, Florida; Secretary of State, Florida State Population Census: 1945, Pensacola, Escambia County, Colored Race, Precinct 55; and Jerrell H. Shofner, "Florida," in The Black Press in the South, ed. Henry Lewis Suggs, 110. 
segment of the NAACP's middle-class constituency." The fight would dominate much of the wartime period as well as continue beyond it. ${ }^{23}$

The NAACP's leadership was dominated by men, but its original emphasis on southern teacher salary equalization cases seemed sincere, particularly considering that the cases, unlike the association's parallel strategy of seeking equal graduate education based on the Fourteenth Amendment's equal protection clause, held no real avenue to more universally applied, precedent-setting Supreme Court decisions. In 1943, Ella Baker became the NAACP's highest-ranking female member when she was appointed Director of Branches. Still, that original enthusiasm waned as time wore on and the cases had mixed success. Walter White described teachers as "the weakerkneed brethren," prone to "chiseling or pussyfooting." Fisk sociologist Charles S. Johnson referred to teachers as "weary" specimens. ${ }^{24}$ It was the language of paternalism, a remnant of the gilded cage that lingered for decades. In 1967, for example, the Student Nonviolent Coordinating Committee's Stokely Carmichael referred to black teachers as race traitors who compromised the movement for the "security and status" of segregated teaching jobs. Despite such rhetoric coming from the NAACP and other male leaders, it was "weary, pussyfooting women" who initiated many of the salary equalization cases that would ultimately bring the NAACP on board. ${ }^{25}$ When the NAACP had trouble finding a teacher willing to file a suit, as it did in Virginia in 1938, the head of the state association, J. M. Tinsley, became frustrated. "We are about to start our membership drive here and the teachers are whispering it around that they are not going to put any money in our drive, because we haven't started on their case," he wrote to Thurgood Marshall, at the time serving as Chief Counsel of the NAACP's Legal Defense Fund. "Of course you will understand the reason why as well as I do. The only thing is I can curse them out and get them told the reason why." ${ }^{26}$

${ }^{23}$ Tomiko Brown-Nagin, Courage to Dissent: Atlanta and the Long History of the Civil Rights Movement (New York: Oxford, 2011), 87-88. Brown-Nagin also makes the case that it was this fight that led to the fight for school equalization, which became a pragmatic alternative to desegregation after Brown; see 88-113.

${ }^{24}$ Kirk, "The NAACP Campaign for Teachers' Salary Equalization," 536.

${ }^{25}$ Ibid.

${ }^{26}$ Baker, "Pedagogies of Protest," 2778; Charles S. Johnson, Growing Up in the Black Belt: Negro Youth in the Rural South (Washington, DC: American Council of Learned Societies, 1941), 104; Kenneth Robert Janken, White: The Biography of Walter White, Mr. NAACP (New York: New Press, 2003), 264; Stokely Carmichael and Charles V. Hamilton, Black Power: The Politics of Liberation in America (New York: Vintage Books, 1967), 14; Confidential Memorandum to Members of the Joint Committee on Teachers' Salaries in Virginia from the Legal Staff, May 
When combined with representations in black male media, the dismissive, patriarchal assumptions coming from NAACP leadership created what Patricia Hill Collins calls a "matrix of domination," wherein "structural, disciplinary, hegemonic, and interpersonal domains of power reappear across quite different forms of oppression." 27 The dominant narrative of civil rights, for example, propagated by male leaders of the NAACP and rival rights groups, emphasized a reclamation of black masculinity, an emphasis given voice by the black press. While Ella Baker and others reached activist leadership roles, and Ethyl Payne climbed the hierarchy of the Chicago Defender, the vast majority of leadership in and philosophy behind most such enterprises was male. Black women were not defined out of the theory and rhetoric of race rights, but their role was necessarily minimized. Despite such a matrix, however, women led the way in the teacher salary equalization fight at the local level. Aline Black became the plaintiff in that Virginia case, saving Tinsley's membership drive. In Charleston, it was Viola Louis Duvall. In Dallas, it was Thelma Page. Valla Abbington in Louisville. Mary White Blocker in Jacksonville. Gladys Noel Bates in Jackson. Women did not initiate every teacher salary case, but they initiated the majority of them, and with the preponderance of affected teachers being women, they always had skin in the game. Not only were the majority of NAACP lawyers and executives men, however, so too were the majority of southern editors who publicized the lawsuits. ${ }^{28}$

\section{The Southern Black Press Mediates the Salary Fight in Florida, Georgia, and South Carolina}

Albert McKeever's Jacksonville Progressive News was founded in 1938 and lasted until the mid-1950s. In April 1941, the paper reported on renewed efforts by Florida teachers to "continue their fight for equal pay." ${ }^{29}$ In October, the paper covered a local teacher who filed a petition with the Board of Public Instruction for equal pay. The move followed a meeting of more than three hundred teachers at a local church to raise money for the Duval County Teachers' Association, created to support the fight for equal pay. "Never before," the paper reported,

13, 1938, NAACP Papers, Library of Congress, Legal Files, Group 1, Box D-91, Cases Supported: Teachers Salary Cases, Virginia (hereafter NAACP Papers); and J. M. Tinsley to Thurgood Marshall, Oct. 7, 1938, NAACP Papers.

${ }^{27}$ Collins, Black Feminist Thought, 18. $535-36$

${ }^{28}$ Ibid.; and Kirk, "The NAACP Campaign for Teachers' Salary Equalization,"

${ }^{29}$ Shofner, "Florida," 110. 
"have we seen such an interest taken by any group to launch a fight for a cause of the Negroes in this city." ${ }^{30}$ An editorial that month praised the woman, Mary White Blocker, for submitting her petition. "A Woman Has Blazed the Way," the paper proclaimed. "Do we have any men to follow in her footsteps? We need better sewerage, better streets, better schools, better parks for our children, better police protection and many more improvements that we are entitled to." 31 They were tangible goals if people started publicly advocating for them. 32

Or, if men did. It was a contradictory message, boldly proclaiming a woman's success but immediately calling on men to meet the community's social needs not specifically gender-coded as female. It was the kind of mediation that ignored the push for abolition, the Progressive Era reform movement, and the swelling ranks of the Women's Army Corps (WAC) and the Women Accepted for Volunteer Emergency Service (WAVES), one that placed a ceiling on women's influence in the public sphere. Septima Clark, Lulu White, and Modjeska Simkins saw no such ceiling, but the efforts of the positive press in gender-coding their efforts while chronicling their success created such barriers for the recipients of that mediation, virtually ensuring future ceilings. ${ }^{33}$

Salary equalization, however, was far from assured. In June 1942, the Progressive News reported on a local school board plan to base salaries on the results of an examination that all Duval County teachers would be asked to take. If they chose not to take the exam, their salaries would be frozen at their current level. The NAACP protested the measure, because white teachers had no real incentive to take the exam, while black teachers had to take a test in hopes of something approximating equalization. Both the NAACP's protest and the publicity the Progressive News brought to the case were important works of advocacy that aided Blocker and her colleagues' fight, and they remained consistent, largely because the Florida salary qualification exams were racially problematic without any gendered differentiation. ${ }^{34}$

30 "Jacksonville Teacher Files Petition for Equal Salary," Atlanta Daily World, Oct. $18,1941,1$.

${ }^{31}$ A Woman Leads The Fight," Atlanta Daily World, Oct. 17, 1941, 6.

${ }^{32}$ Shofner, "Florida," 110; and N. W. Ayer \& Son's Directory of Newspapers and Periodicals (Philadelphia: NW Ayer \& Son, 1953), 173.

${ }^{33}$ Linda K. Kerber, No Constitutional Right to Be Ladies: Women and the Obligations of Citizenship (New York: Hill and Wang, 1998), 221-36.

34"Florida Teachers Offered 'Compromise' Salary Plans," Atlanta Daily World, June 16, 1942, 1; "Federal Aid to General Education," in CQ Almanac 1946, 2nd ed., 04-643-04-651 (Washington, DC: Congressional Quarterly, 1947); and Timothy J. Conlan and Advisory Commission on Intergovernmental Relations, 
In 1940, the venerable Savannah Journal, founded in 1918, hired a new editor: Dr. Asa H. Gordon, who was also the Director of the Divisions of Social Sciences and Research Publication at Georgia State College (now Savannah State). "Dr. Gordon is a man of culture and fine character and by study and contact possesses a very excellent education," said M. F. Whittaker, president of South Carolina State. "I think of him as an able educator, a brilliant scholar, and a cultured gentleman." ${ }^{35}$ In August 1941, however, the Georgia State chancellor dismissed Gordon over editorials he published in the Journal about the salaries of black and white professors. Sanford Beaver, the white chairman of the Board of Regents, sent a letter to alumni defending the dismissal. Gordon accepted the position knowing what the salary was, and therefore had no right to argue, Beaver claimed, and certainly had no right to argue in public. His attitude "seemed calculated to injure the faculty morale of our fine Savannah unit, with the result that the Chancellor thought it would be more appropriate for Prof. Gordon to wage his fight for equal salaries from the outside, rather than from inside of the University System." 36

Gordon's fight for equal salaries in the professoriate concerned a male faculty, and after his release made him solely an editor, he used his paper to publish an editorial criticizing black teachers in the area, a mostly female faculty, for not fighting for pay equalization. In March 1942, the Journal ran an editorial from the Atlanta Daily World complimenting the courage of local teachers in filing a suit in federal court asking for salary equality. The suit, filed by a male junior high school and the NAACP, was supported by black teachers across Atlanta, who "have agreed upon a systematic plan of raising the necessary funds to prosecute their case if need be." ${ }^{77}$ It was the kind of organization that had yet to come to Savannah. Gordon's castigation of local teachers could be read as an elevation of the largely female group, assuming that they were on the same plane as the male professors and thus hoping to get all educators on the same page. It could also be read, however, as talking down to what he saw as a more timid, feminine group.

The following month, Gordon wrote an open letter to Georgia's white teachers, encouraging them to support equalization and join the

\footnotetext{
Intergovernmentalizing the Classroom: Federal Involvement in Elementary and Secondary Education (Washington, DC: Advisory Commission on Intergovernmental Relations, 1981), 20.

35 "Gordon Enters Race For State Teachers' Head," Atlanta Daily World, March 20, 1941, 1 .

36 "Social Science Head of Ga. State College Gets Important Role," Atlanta Daily World, Aug. 25, 1941, 2.

37 "Southern Civilization: Events and Comments," Atlanta Daily World, March 9, 1942, 6.
} 
chorus of their colleagues across the South. Equalization meant taking teacher pay seriously, and teacher pay in Georgia for all teachers, white and black, was "far below the requirements for maintaining the American standard of living for any professional group." In addition, "Any federal aid to Georgia which will benefit Negro education will also benefit white education." The open letter, published on the occasion of the annual meeting of the state teachers' association in Savannah, reminded teachers that equalization was "the first step toward democratic education" in the state, "as paradoxical as this may seem to some blinded with racial bigotry. We hope there are few of these among you." 38

In December, the paper chided Atlanta's Board of Education for suspending the male junior high instructor who originally filed suit. The move "clearly reveals the common purpose of the board is to coerce the Negro teachers of the Atlanta system and compel them to keep out of any effort for equalization of salaries in Georgia." The editorial used North Carolina as a counterexample, lauding the state for responding positively to the equalization movement and celebrating the movement's principal proponent, James E. Shepard, president of North Carolina College for Negroes. It quoted an influential white newspaper in the state calling Shepard "the Booker T. Washington of his race in North Carolina." William Reeves of David T. Howard Junior High School and the NAACP was doing much the same in Georgia, though the state wasn't treating him as such, and so the paper pledged "to stand squarely by" him in his fight. ${ }^{39}$

It was the Progressive News strategy in reverse, a different kind of gender-coding that found male activists worthy of public celebration in a fight that was dominated by women. To be certain, the Journals praise for Reeves was not misplaced, as he was fired for his advocacy, but he was one of many teachers, the majority of them women, who were working for equal pay in Atlanta. When that gender selectivity was combined with Gordon's coverage of North Carolina, using the male university president as an exemplar of the state's salary equalization activism rather than one of the teachers with far more skin in the game, the paper created a damsel-in-distress vision of advocacy, wherein men championed other men for saving female victims from the bad behavior of a third, more dastardly, group of men. ${ }^{40}$ $1942,6$.

38 "Southern Civilization: Events and Comments," Atlanta Daily World, April 23,

39 "Courageous Reeves A Fitting Example Against Discrimination," Atlanta Daily World, Dec. 27, 1942, 4.

${ }^{40}$ Damsel-in-distress scholarship focuses most helpfully on European literature, made possible by the evolution of patriarchal models and their inclusion in the fables 
Just up the coast, in South Carolina, was John Henry McCray's Lighthouse \& Informer, founded in 1939. In a September 1941 editorial, the Lighthouse \& Informer analyzed a new law providing a "slight pay increase" for black teachers. It was a law that "may mean a few dollars more for the colored teachers," the paper explained, but "it has done nothing toward "equalizing teacher pay."' ${ }^{11}$ It also noted that teachers were paid mostly by the state, supplemented by the county, and while the state payment was to increase, nothing was to stop the counties from limiting their contributions in equal measure. With the national movement for equalizing teacher salaries under way, the South Carolina law was a half measure at best. Soon, however, the law turned out to be even less than that, as the governor, working in conjunction with the Palmetto State Teachers Association, told black teachers that they had to go through a process of qualification to prove themselves equal to white teachers. The Lighthouse \& Informer denounced the "appeasement plan," calling the notion of qualification "fallacious." ${ }^{2}$

The teacher salary equalization issue was never far from the top of McCray's agenda. One of the dominant strategies for equalization in South Carolina was the use of Ben D. Wood's National Teacher Examination to demonstrate the functional equality of black teachers to their white counterparts. Other standards included education and time served. In May 1944, the Charleston County School Board created a new salary schedule that provided a measure of equalization based on a teacher's years of college and years of service to the school system. But a measure of equalization was not full equalization, and the county did its best to use creative accounting to keep white teachers with greater salaries. It was the kind of deliberate speed that the Deep South would use time and again to avoid equality policies of all kinds, but teacher salary equalization delays were even more frustrating to

and novels of the Continent. For more about damsel-in-distress scholarship, see Jackie C. Horne, History and Construction of the Child in Early British Children's Literature (Burlington, VT: Ashgate, 2011), 196-200; and Herman Pleij, "The Late Middle Ages and the Rhetoricians, 1400-1560," in A Literary History of the Low Countries, ed. Theo Hermans (Rochester, NY: Camden House, 2009), 81-83.

41 "Saboteurs and Equal Pay," Atlanta Daily World, Dec. 26, 1941, 6.

${ }^{42}$ Peter F. Lau, Democracy Rising: South Carolina and the Fight for Black Equality Since 1865 (Lexington: University Press of Kentucky, 2006), 136-44; John Egerton, Speak Now Against the Day: The Generation Before the Civil Rights Movement in the South (Chapel Hill: University of North Carolina Press, 1995), 227-28, 287-88; Danielle L. McGuire, "It Was Like All of Us Had Been Raped: Sexual Violence, Community Mobilization, and the African American Freedom Struggle," Journal of American History 91, no. 3 (Dec. 2004), 909, 930; and J. Thomas Wilson to John H. McCray, Sept. 28, 1941, R1347a (41-44), John Henry McCray Papers, South Caroliniana Library, The University of South Carolina, (hereafter McCray Papers). 
McCray, considering the length of time that the Lighthouse had been advocating for the change. ${ }^{43}$

In March 1945, the southern and western regions of the National Negro Publishers' Association (NNPA), with McCray attending and C. A. Scott serving as vice president for the southern region, called for a special meeting at Mississippi's Jackson College "to work out strategy for fighting for equal education in the Southern States," particularly in response to the Supreme Court's 1938 Missouri ex rel. Gaines decision mandating that states provide black educational opportunities equal to that of whites, either through integration or the creation of equivalent institutions. ${ }^{44}$ McCray was hopeful, writing the Atlanta Daily World's C. A. Scott that he was convinced that the March meeting "was a turning point in our section and that a new trade and a new south are the inescapable results." ${ }^{45}$ At that meeting, the group created the Southern Negro Conference for Equalization of Educational Opportunities, with the Houston Informer's Carter Wesley as president, C. A. Scott as vice president, and McCray as a committee member. It was, however, an all-male committee and focused its attention on collegiate education and voting rights. The NNPA had been founded in 1940 to coordinate the efforts of black publishers throughout the country. Still, it was an organization dominated by men, representing a business dominated by men, and thus it kept its equalization efforts to male-dominated higher education, not out of malice but out of tunnel vision. ${ }^{46}$

Perhaps the core of the southern teacher salary equalization fight and its intersection with black male journalism came in Alabama. In March 1941, a staff writer at Montgomery's Alabama Tribune reported on the state's attempts to avoid paying equal salaries to black teachers. White leaders suggested "lowering the pay of white teachers, cutting the school term," or attempting a version of equalization "by an additional outlay of $\$ 2,000,000$ by the State Legislature," all plans designed simply to create resentment among the white population and to make

${ }^{43}$ R. Scott Baker, Paradoxes of Desegregation: African American Struggles for Educational Equity in Charleston, South Carolina, 1926-1972 (Columbia: University of South Carolina Press, 2006), 48-53; and M. A. Mouzon to John H. McCray, May 30, 1944, R1347a (41-44), McCray Papers; and Alma G. Forrest to John H. McCray, n.d., R1347a (45), McCray Papers.

${ }^{44}$ NNPA circular letter, March 5, 1945, R1347a (45), McCray Papers.

${ }^{45}$ John H. McCray and C. A. Scott, March 10, 1945, R1347a (45), McCray Papers.

${ }^{46}$ C. A. Scott, "Combined Report of the Southern and Western Vice-Presidents," Minutes of the Limited War-Time Conference of the NNPA, July 27-29, 1945, R1347a (45), McCray Papers. 
them feel slighted in what they saw as a zero-sum game of rights. ${ }^{47}$ "All these 'tactics and schemes' have been detected by Negro educators," the paper reported. Teacher salaries were no longer just an issue for teachers; they were an issue for everyone. "Sentiment seems to be, to use the phrase of a Montgomery newspaper editorial, 'devoted to making the American schools absolutely free and equal."'48 It was an important, racially divisive issue, but even in its clear stand on the side of pay equity, the article remained guarded, letting its reporting make its case and couching its complaints in quotation marks and attributions. Schemes by lawmakers to lower the pay of white teachers or cut the school term were not simply "appeals to resentment"- they were "interpreted by Negro thinkers" as appeals to resentment. ${ }^{49}$ The paper made its case carefully, plying a practical effort to explain the issue to its readers and point them in the direction of advocacy without expressly engaging in that advocacy itself, for fear of courting retribution for the attempt at what some Alabama whites were sure to see as demeaning their children's education.

Such was another hindrance to the black southern press's full participation in the teacher salary equalization fight. The black southern press in the post-World War I period became the modern version of antebellum kinship networks. They looked much the same and served similar ends in small towns of the southern countryside. Calls for land reform were replaced with calls for voting rights, but the authors of that new network had learned from earlier racial crackdowns. In a pragmatic effort to avoid such confrontation developing from white fear, newspaper editors developed a practical radicalism that argued on the fringes of racial hegemony, picking their spots, urging local compromise, and saving their loudest vitriol for tyranny that wasn't local and thus left no stake in the game for would-be white saboteurs. "To be black and Southern in those perilous times, and to stake out a position at variance with the canons of segregation and white supremacy," explains historian John Egerton, "required a mixture of conservatism and tactful independence that few non-Southerners could understand or appreciate. Patience and diplomacy and flank-covering caution were essential to survival." 50

Practical radicalism here bears an affinity to Tamiko BrownNagin's "pragmatic civil rights," a term she used to describe Atlanta leadership's effort to "preserve the economic self-sufficiency that

\footnotetext{
47 "Schemes and Tactics Used to Deter Just Teacher Wage Levels," Atlanta Daily World, March 17, 1941, 1.

${ }^{48}$ Ibid.

${ }^{49}$ Ibid.

${ }^{50}$ Egerton, Speak Now Against the Day, 285.
} 
black elites had achieved under Jim Crow, expand black political influence, and preserve personal autonomy." ${ }^{51}$ So litigation in an effort for civil rights was a last resort for that leadership, and integration was not a necessary measure of equality. Brown-Nagin's evaluation of the legal fight for civil rights in Atlanta argues that local communities were the locus of functional change. Community members were "law shapers, law interpreters, and even law makers," and thus the story of the fight for rights in the nation expands by uncovering "the agency of local people." 52 The law shapers and law interpreters in local communities throughout the South and the nation, most of them much smaller than Atlanta, were the small black newspapers that acted as interpreters of the larger world. And one of the core southern equality claims not rooted in integration was the fight for teacher salary equalization.

\section{The Southern Black Press Mediates the Salary Fight in Alabama}

One of the most significant southern interpreters of teacher salary equalization and other rights efforts was the Birmingham World, edited by Emory O.Jackson. The Birmingham World had been publishing since the early 1930s, but Jackson took over editorial duties for the paper in 1941 and would remain in that position until 1975, using the paper to fight for civil rights in one of the most notoriously racist cities in the South. He would also lead the Alabama conference of the NAACP. He was, unlike many of his other male editors who acted as mediators of the salary equalization fight, an activist away from the newspaper. ${ }^{53}$

Jackson's sister Ruby Jackson Gainer was a teacher in the city who helped lead the fight for pay equalization in Birmingham schools, aided by her brother and the Southern Negro Youth Congress, an organization assumed by the FBI to be a "negro Communist front in Birmingham." 54 Jackson was a member of the Southern Negro Conference for Equalization of Educational Opportunities, along with C. A. Scott, Wesley, and McCray, and worked diligently, like his sister, for equal education. His relationship to the cause, however, was personal, and thus the scope of his coverage and his activism would appear less paternalistic in its mediation to the Birmingham public than

\footnotetext{
${ }^{51}$ Brown-Nagin, Courage to Dissent, 2.

${ }^{52}$ Ibid., 8.

${ }^{53}$ Gene Roberts and Hank Klibanoff, The Race Beat: The Press, the Civil Rights Struggle, and the Awakening of a Nation (New York: Vintage Books, 2007), 50; and 1944 Desk Planner, box 7, Emory O. Jackson Papers, A423, Birmingham Civil Rights Institute, Birmingham, Alabama.

${ }^{54}$ Memorandum: Special Agent in Charge, Birmingham to Director, FBI, July 17, 1946, FBI Headquarters file 100-HQ-345671, Federal Bureau of Investigation, Washington, DC.
} 
many of his male colleagues, serving as an exception that proved the rule, so to speak. ${ }^{55}$

Gainer had been teaching in the Jefferson County system for fourteen years and was president of the Alabama State High School Teachers Association. When she was fired for fighting for equal pay, Jackson lobbied for NAACP intervention in the case. It was "purely intimidation designed to scare the teachers" from fighting for salary equalization. "What steps best to take at this point I am unable to say," he told Teachers Association leaders, but he did want the plan to be comprehensive. "I feel that we should mobilize public sentiment, organize coalition action, demand a public hearing, test the teachers tenure act, and fight the case clear up to the US Supreme Court." ${ }^{56}$

In April 1945, a federal judge enjoined and restrained the Jefferson County Board of Education from pay discrimination based on race. A report in the Birmingham Post in November 1946 revealed that 55.6 percent of black teachers in the county held degrees and that the number continued to grow. That month, Jackson wrote to the local school board asking if the World could have a reporter at their meetings to ensure that the equalization of teacher salaries was being complied with as ordered by the courts. The board agreed "because we hold no secret sessions and we have nothing to conceal," although the return letter did claim that the process might take up to three years and that "there is no binding agreement as to non-degree teachers." The board wanted "to be fair and equitable in all of our dealings with all of our teachers and we are trying to make adjustments as rapidly as possible." 57

By January 1947, even the white Birmingham News endorsed equal pay, but the school board continued to push back. On May 1, Gainer received her termination notice, the board citing "insubordination, neglect of duty and other good and just causes." ${ }^{58}$ In June, the Birmingham branch of the NAACP launched its Legal Defense and Education Fund campaign. Jackson, chairman of the Defense Fund,

${ }^{55}$ Ibid.; Birmingham World, March 27, 1942, 7; and circular letter from Carter Wesley, March 25, 1946, 1102.29.2, Birmingham World Office Files, Birmingham Public Library Department of Archives and Manuscripts (hereafter Birmingham World Office Files).

${ }^{56}$ Emory O. Jackson to Hartford Knight and E. W. Taggart, May 5, 1947, 1102.1.1.16, Birmingham World Office Files; and Christopher Brian Davis, "Emory O. Jackson: A Traditionalist in the Early Civil Rights Fight in Birmingham, Alabama" (master's thesis, University of Alabama at Birmingham, 2006), 83-85.

${ }^{57}$ W. I. Pittman to Emory O. Jackson, Dec. 2, 1946, 1102.29.2, Birmingham World Office Files.

${ }^{58}$ J. E. Bryan to Ruby Jackson Gainer, May 6, 1947, 1102.1.1.16, Birmingham World Office Files. 
was still working to raise money in September 1948 despite legal setbacks and physical attacks. ${ }^{59}$

Jackson's plan to fight the firing of Gainer and her colleagues in Jefferson County was many-faceted. He wanted "outstanding white and Negro citizens" to write members of the school board. He also hoped to convince organizations to pass resolutions and people to sign petitions against the actions. He wanted the Alabama State Teachers Association (ASTA) and its corresponding principals group to "make a favorable statement on behalf of Mrs. Gainer." He was doubtful it would happen, however, as "several ASTA higherups in Birmingham appear to be parties to the frame-up firing of tenure and non-[tenure] teachers." ${ }^{0}$ Again, however, that case was made at a meeting of the NAACP rather than in a scathing editorial in the World, as Jackson convinced the group to launch a Teacher Defense Fund Drive to raise a thousand dollars for the equalization suit. His newspaper covered the drive, but without editorial comment. Such was the nature of the mediation of the black press. Jackson could be far more radical on behalf of his sister and her colleagues as leader of the local NAACP than he could ever be in his newspaper, the result of a different kind of coding, one that made southern newspapers responsive both to social mores within the black community and fear of white reprisal when it came to journalistic activism against local white whims. ${ }^{61}$

In June 1948, Jackson sent a circular to NAACP members in Birmingham explaining the case. Black teachers wanted $\$ 300,000$ "in unpaid differential salaries, growing out of an alleged violation of a non-discrimination of decree of the Federal Court." 62 Letters from around the country flooded the Jefferson County Board of Education urging the restoration of Gainer's job and equalization of pay. Sara Walsh, director of the National Teachers Division of the Congress of Industrial Organizations (CIO), wrote the Pittsburgh

${ }^{59}$ Emory O. Jackson to E. W. Taggart, May 12, 1947, 1102.1.1.16, Birmingham World Office Files; Bolden v. School Board of Jefferson County, No. 5339 Civil Docket, Final Decree, April 29, 1945, Box 9 (1940s), Birmingham World Office Files; Highlight Dates in the Anti-Salary Discrimination Campaign," Box 9 (1940s), Birmingham World Office Files; and "Teachers Defense Fund Sunday, Sept. 19, 1948," Box 9 (1940s), Birmingham World Office Files.

${ }^{60}$ Emory O. Jackson to J. E. Pierce, May 12, 1947, 1102.1.1.21, Birmingham World Office Files.

${ }^{61}$ Birmingham World, Aug. 10, 1948, 1; Birmingham World, Aug. 17, 1948, 1; Birmingham World, Aug. 27, 1948, 1; Anne G. Rutledge, Emory O. Jackson: Warrior (Self-published: CreateSpace, 2014), 78-94; and Davis, "Emory O. Jackson," 85-94.

${ }^{62}$ Circular letter from the NAACP Birmingham Branch, Sept. 8, 1948," 1102.1.1.3, Birmingham World Office Files. 
Courier asking for coverage of the Birmingham fight. There was also a letter-writing campaign to Alabama governor James Folsom urging action in the case. The World reported on such news when it happened, but Jackson saved his most ardent activism for when he was away from his typewriter. Again, social mores and southern journalistic precedent offered him little choice. ${ }^{63}$

And so a successful resolution for black teachers would be slow in coming, and the salary equalization problem in Birmingham would stretch into the next decade. In October 1950, Jackson provided a detailed report on the front page of his paper citing funding differentials for every school in Birmingham. "It is estimated," wrote Jackson, "that $\$ 116$ more is spent on a white high school student than on a Negro," a figure that "by no means narrow $[\mathrm{s}]$ materially the differential gap in education under the "Separate but Equal doctrine." 64 The report, based on numbers released by the city's board of education, focused on building funds at white and black Birmingham schools, but such discrepancies only served to reemphasize the similar funding differentials in teacher pay. Such was the kind of nongendered coverage that was not available in other southern newspapers with modest circulations and male editors. Jackson, however, in his relationship to Gainer and his activism outside the newspaper, made his circumstance fundamentally different than those of his editorial counterparts. Jackson's penchant for civil rights activism also played a role in his gender-neutral coverage, as a similar penchant motivated Gainer's principal, William Bolden, who had filed the original complaint five years prior to Gainer's formal involvement in 1942. It was Bolden's original case that led to a ruling enjoining the school board from paying less to black teachers solely on the basis of race. ${ }^{65}$

In June 1951, the World responded to the federal court decision ruling that black public school facilities in Clarendon County, South Carolina, were unequal to those for white students and ordering officials to move immediately toward equalization and to report their

${ }^{63}$ Ruby Jackson Gainer to NAACP Birmingham Branch, June 27, 1948, 1102.1.1.3, Birmingham World Office Files; D. A. Gallimore to W. A. Berry, June 6, 1947, 1102.1.1.16, Birmingham World Office Files; Robert M. Ratcliffe to Sarah T. Walsh, June 5, 1947, 1102.1.1.16, Birmingham World Office Files; Marvin Nichols to James E. Folsom, June 27, 1947, 1102.1.1.3, Birmingham World Office Files; Muriel Draper to James E. Folsom, June 27, 1947, 1102.1.1.16, Birmingham World Office Files; Birmingham World, Aug. 27, 1948, 1; and Davis, "Emory O. Jackson," 85-94.

64"Educational Differentials Still Exist In Birmingham School Setup," Birmingham World, October 31, 1950, 1.

${ }^{65}$ Gainer v. School Board of Jefferson County, Alabama, 135 F. Supp. 559 (N.D. Ala. $1955)$. 
progress. It was "the first such verdict that has been rendered regarding public school facilities in a deep-south state," and the World classed it as "a significant victory." The plaintiffs had asked for an end to segregation. That didn't happen, and the paper acknowledged the disappointment, but chose to emphasize the victory of equalization over and against the defeat of desegregation. ${ }^{66}$

In June 1953, Bill Nunn, the World's managing editor, urged Jackson to take over a project documenting educational inequality in the South. He wanted numbers on spending and school enrollment; there had to be a corollary to the moral case. "In trying to prove to our reading public that the south's theory of 'separate but equal' will never work educationally," he argued, "we must get the facts and figures." ${ }^{67}$ Jackson responded by writing Tuskegee University, which sent him assembled data from 1936 to 1951 . The numbers were stark, demonstrating massive disparities in enrollment, building values, and capital outlay per student. Spending for black pupils was only 30 percent of spending for white pupils in the 1936-1937 school year. That disparity had shrunk through the remainder of the 1930 s and 1940s, reaching just below 72 percent by the 1950-1951 school year, but even that progress left a vast spending gap that disadvantaged Alabama's black students in immeasurable ways, particularly when broader capital outlay, building values, and other figures became part of the calculus. ${ }^{68}$

Again, the lack of paternalism in the World's coverage was largely due to Jackson's relationship with the plaintiff in the equalization case, and again, such is not to say that the papers' reporting was not published with good intentions or that it was not helpful in securing public school teachers better salaries. But in several such reportings, paternalism played a significant role. In other gendered controversies during World War II, for example, such as the rape of Recy Taylor, that same problematic mediation was evident. On September 3, 1944, Recy Taylor was kidnapped while leaving church and raped by six white men, who admitted the crime to police. Still, they were never indicted, igniting protest from the black community in Alabama and across the country. Among them was E. G. Jackson, editor of the Alabama Tribune, who teamed with Eugene Gordon from the communist Daily Worker to confront Alabama governor Chauncey Sparks and

\footnotetext{
${ }^{66}$ Birmingham World, June 26, 1951, 6.

${ }^{67}$ William G. Nunn to Emory O. Jackson, June 24, 1953, 1102.1.1.16, Birmingham World Office Files.

${ }^{68}$ C. G. Gomillion to Emory O. Jackson, July 6, 1953, 1102.1.1.16, Birmingham World Office Files; and C. G. Gomillion, "Racial Differentials in Public Education in Alabama," 1102.1.1.16, Birmingham World Office Files.
} 
demand an investigation into the case. Jackson helped organize meetings and generate petitions, along with allies such as E. D. Nixon, Rosa and Raymond Parks, Rufus Lewis, and Johnnie Carr. It was the leadership group that would, argues Danielle McGuire, "lift Martin Luther King, Jr., to international prominence a decade later, after their leading organizer was arrested on a Montgomery bus." 69

Taylor's case was a symbol of the age. An all-white, all-male jury dismissed the case in October 1944. After months and months of activism, led by the black press and, in particular, by Rosa Parks, the attorney general finally sought a grand jury indictment. But that jury, too, was all-white and all-male, and in February 1945, it failed to indict any of the suspects. It was a verdict that stunned and frustrated black Montgomery, one that McGuire has described as bringing "the building blocks of the Montgomery bus boycott together a decade earlier."70 Those building blocks, however, could only be gathered by the coverage of the black press. "Decency calls for the protection of womanhood," wrote Emory Jackson in the World. "Permit womanhood anywhere to be abused, you leave it without sufficient protection everywhere. Erring men who escape punishment in one instance will feel no restraint against any woman anywhere. If in the interest of selfish idealism, the Grand Jury should feel impelled to indict the guilty." 71 The World made the case that allowing crimes against black women was simply a gateway to crimes against white women. ${ }^{72}$

\section{The Southern Black Press Mediates the Salary Fight in Arkansas, Louisiana, and Kentucky}

It was a calculated paternalism, to be sure, as Jackson used familiar tropes in an effort to urge prosecutions for Taylor's attackers. Those constructs, however, so familiar to the men who might be convinced to indict, were also the same ones that Jackson's fellow male journalists were using to promote teacher salary equalization. Through Taylor's recovery and the teachers' wage fight, it was the ideas themselves that remained constant. Of course, the most common display of such journalistic tropes in the wartime period appeared in coverage of the teacher salary equalization fight through the rest of the South. The Arkansas World, for example, a paper created by the SNS to compete

\footnotetext{
${ }^{69}$ Danielle L. McGuire, At the Dark End of the Street: Black Women, Rape, and Resistance (New York: Knopf, 2010), 26.

${ }^{70}$ McGuire, At the Dark End of the Street, 39.

71 "Take Up the Case," Atlanta Daily World, Sept. 19, 1945, 6.

${ }^{72}$ McGuire, At the Dark End of the Street, 6-39; and "Take Up the Case," Atlanta Daily World, Sept. 19, 1945, 6.
} 
with Little Rock's more established Arkansas State Press, covered salary equalization events centering around Little Rock's Dunbar High School. Called by Mark Tushnet the "most important salary suit of the 1940s," and described in detail by historian John Kirk, the Little Rock case sought to remedy vast racial disparities in public school teacher pay. For the 1941-1942 school term, black primary school teachers made an average of $\$ 331$, while their white counterparts made an average of $\$ 526$. The secondary school rates were $\$ 567$ and $\$ 856$, respectively. The local Classroom Teachers' Association created a Salary Adjustment Committee, both dominated by African American women, to plan a case with the aid of the NAACP. Ultimately, Dunbar's English Department chair, Susie Morris, headed the lawsuit. ${ }^{73}$

Thurgood Marshall, who handled the Little Rock case, wrote to assistant NAACP secretary Roy Wilkins, impressed with the women leading the charge. "These Southern Teachers have acquired new backbones," he wrote. ${ }^{74}$ The black press coverage, however, would be less enthusiastic about its female leaders. Both the Arkansas World and Arkansas State Press, the city's two leading black papers, covered the equalization fight. The State Press, led by L. C. Bates and his wife Daisy Gaston Bates, praised the NAACP and the steps the case was taking "in the direction of liberalism and Americanism." 75 What coverage remains was wholly supportive, but the State Press had a strong female influence in Daisy Bates, who would later head the state NAACP and spearhead Little Rock Central High School's 1957 desegregation, and the remaining coverage is sparse. The World, too, supported the effort, but focused its principal sympathy not with Susie Morris but with Dunbar's principal, John H. Lewis instead. In May 1943 , Lewis submitted his resignation after fourteen years under pressure from the school board, largely because of his participation in the equalization suit, which was finally tried in October 1942. The principal expressed no regret, arguing that to cooperate with his superiors against his black faculty would have been "contrary to his principles of justice and right." 76 The World covered the resignation with undisguised gratitude. "World history records that every great movement of any worth required the martyrdom of a strong and courageous character of the times before success was accomplished," the paper explained.

\footnotetext{
${ }^{73}$ Mark V. Tushnet, The NAACP's Legal Strategy Against Segregated Education, 19251950 (Chapel Hill: University of North Carolina Press, 1987), 90-92; and Kirk, "The NAACP Campaign for Teachers' Salary Equalization," 536-39.

${ }^{74}$ Kirk, "The NAACP Campaign for Teachers' Salary Equalization," 539.

${ }^{75}$ Arkansas Gazette, March 8, 1942, 8.

76 “College President Defines Education," Atlanta Daily World, May 6, 1940, 6.
} 
"The Negro teachers and citizens of Little Rock and Arkansas possess such a martyr to the cause of equal citizenship and rights." ${ }^{77}$ By all reasonable standards, the paper's martyr should have been Morris, but instead it was the man who resigned in sympathy with her cause.

In Grambling, Louisiana, a Lincoln Parish town just south of the Arkansas border, the Bayou State Register was published by Collie J. Nicholson, sports information director for Grambling College. In 1951, a Register editorial castigated S. L. Jones, editor of the Southern Advocate, another north Louisiana black weekly, and appointee to Governor Earl Long's Civil Defense Advisory Board. Jones claimed, "Our teachers are being paid better salaries than any other state in the Union,"78 which was decidedly wrong, and which the Register saw as a way to excuse the administration, even though Louisiana's black teacher pay still had not arrived at equalization more than a decade after that particular movement had materialized. It was "a typical example of the type of stuff some Negroes spout out in an attempt to keep white people thinking they are "all right." Jones and those of his ilk "stand in a despicable and unsavory light" and did far more harm than good. ${ }^{79}$ It was a direct shot at another black editor in a state without very many black editors. At the same time, however, it was not a sustained fight for teacher pay, its trajectory aimed not at advocating for a predominantly female teaching corps but instead at disparaging a male rival.

In Kentucky, the Louisville Independent News, another male-owned paper associated with the SNS, covered the December 1939 report of a special committee appointed by Kentucky governor Happy Chandler to study equal education in the state. The report recognized the legal right of black students to attend the University of Kentucky and other institutions of higher learning. Plans for the transition, however, remained in process. In October 1941, almost two years after Chandler's committee report, student Charles Eubanks filed his second complaint against the University of Kentucky, suing for undergraduate admission to the school. The case would drag on for years and Eubanks would eventually drop the case in 1945. But the News would cover it until the end, rightly interpreting Eubanks as a symbol of the racial divisions in Kentucky higher education and the failure of the government to live up to its earlier promises. ${ }^{80}$

\footnotetext{
${ }^{77}$ As published in "Dunbar School Principal Gives Up Under Pressure," Atlanta Daily World, May 29, 1943, 5.

${ }^{78}$ As published in "So Unnecessary!" Atlanta Daily World, May 30, 1951, 6.

${ }^{79}$ Ibid.

80 "Legal Rights To Attend Univ. of Ky. Recognized by Governors Committee," Atlanta Daily World, Dec. 1, 1939, 6; "Eubanks Files New Suit Against Kentucky
} 
Covering the men involved in higher education equalization fights was a fundamentally different endeavor than the gendered effort to equalize teacher salaries in public schools, but the News was diligent about responding to both efforts. In November 1940, a Louisville teacher, with the aid of the NAACP, joined the chorus of her southern counterparts and petitioned the board of education to make her salary equal to those of white teachers, beginning the process of equalizing all black teachers' salaries. The Independent News covered the effort in depth, prompting the school board to act quickly and agree in January 1941 to equalize salaries beginning with the new school year in September. Thurgood Marshall, representing the NAACP, refused to drop the suit, however, arguing that "it is desirable to have some sort of decree in this matter so that the question will not come up again." 81 It was a good strategy. White school boards had not proven particularly trustworthy. The trial was set for October, but again he would be disappointed by Kentucky, as the teachers agreed with the court's dismissal that month after signing new contracts that gave them equal pay. The female teachers were uninterested in being dictated to by men who assumed they knew best, whether they be white politicians or NAACP lawyers. The teachers just wanted equal pay. ${ }^{82}$

The gendered divisions in education, however, went further. The month prior to Chandler's equal education report, the Independent News interviewed an incumbent state legislator running for reelection as to the status of the "Married Teachers' Law," a statute that disallowed schoolteachers from marrying until they had accrued five years of teaching experience. ${ }^{83}$ It was a bizarre sexist holdover that only three states still maintained, but the most telling part of the News's story was the interview itself, treated as an afterthought by the paper. But most papers south of Louisville didn't have that kind of

Univ.," Atlanta Daily World, Oct. 21, 1941, 1; John A. Hardin, "Kentucky Is More or Less Civilized': Alfred Carroll, Charles Eubanks, Lyman Johnson, and the Desegregation of Kentucky Higher Education, 1939-1949," Register of the Kentucky Historical Society 109, no. $3 / 4$ (Summer/Autumn 2011), 327-50; and Luther Adams, Way Up North in Louisville: African American Migration in the Urban South, 1930-1970 (Chapel Hill: University of North Carolina Press, 2010), 99-104.

81 "Kentucky Teacher Seeks To Equalize Salary With White," Atlanta Daily World, Nov. 14, 1940, 1.

82 "Lawyers Continue Teachers' Fight Despite Board of Education," Atlanta Daily World, May 30, 1941, 4; "Ky. Teachers' Salary Case Up This Fall," Atlanta Daily World, Aug. 5, 1941, 1; Adams, Way Up North in Louisville, 90-4; and John A. Hardin, Fifty Years of Segregation: Black Higher Education in Kentucky, 1904-1954 (Lexington: University Press of Kentucky, 1997), 71-72.

83 “Anderson Makes Statement on Married Teachers' Law," Atlanta Daily World, Nov. 7, 1939, 6. 
access to white legislators, and those who did usually were not interviewing legislators about race-neutral issues. It was something of a watershed precisely because it was not a watershed.

\section{Conclusion}

Glenna Matthews argues that the historical gender gap in America developed through a constant battle over access to the public sphere. Certainly this battle was more than territorial, and for the bulk of history this battle was relatively one-sided, but through the conscious, often incremental ventures of women, public space in all its formscultural, political, legal, and semantic- began opening to include both genders. It was how women were able to enter the educational profession to begin with. ${ }^{84}$ The pushback against such gains was many-faceted. Sara Evans emphasizes the cycle of contradictory presentation of women's roles and the psychological frustration it engendered in the decades emerging from World War II. As women began to criticize those roles, they only provoked further backlash, from both men and a significant number of women. In July 1946, the year following the war's end, for example, the Equal Rights Amendment again went down in defeat. ${ }^{85}$

Black women, and black teachers in particular, entered that world at their peril, gripped by the double bind of race and gender and fighting the tropes of both in activist fights like salary equalization. Unlike the general trend of civil rights, then, black and white women moved steadily from unified advocacy to separate striving, seeing less and less in common with each other as years and issues passed. ${ }^{86}$ In instances like teacher salary equalization, however, black teachers were already striving separately. And they were lobbying for equal pay and increased higher echelon job opportunities. While the salary equalization movement did not achieve a seminal legal victory that provided blanket equalization for black teachers, it did, in most instances, improve the salaries of black teachers, convince the NAACP that creating a more viable equality within "separate but equal" schools was a

${ }^{84}$ Glenna Matthews, The Rise of Public Woman: Woman's Power and Woman's Place in the United States, 1630-1970 (New York: Oxford University Press, 1992).

${ }^{85}$ Sara Evans, Personal Politics: The Roots of Women's Liberation in the Civil Rights Movement and the New Left (New York: Knopf, 1979); and Cynthia Harrison, On Account of Sex: The Politics of Women's Issues, 1945-1968 (Berkeley: University of California Press, 1988).

${ }^{86}$ Jane Sherron De Hart, "Second Wave Feminism(s) and the South: The Difference That Differences Make," in Women of the American South: A Multicultural Reader, ed. Christie Anne Farnham (New York: New York University Press, 1997), 273-301. 
nonstarter and that attacking segregation itself would be the most effective strategy, and grew the NAACP in the South. ${ }^{87}$

It also put black women at the forefront of the civil rights fight. Jacquelyn Dowd Hall's seminal essay on the long civil rights movement moved our understanding of the movement back to the period of the late New Deal, just as the salary equalization fights were beginning. Ella Baker, for example, would pass on the organizational leadership she acquired as Director of NAACP Branches in the early 1940s to SNCC. Daisy Bates would lead Little Rock's desegregation fight. Septima Clark would continue her activism into the 1980s. Their work would exist alongside that of leaders like Fannie Lou Hamer and Diane Nash, and then later Elaine Brown and Angela Davis. There was some pushback against school integration from some black educators, leading to Carmichael's criticism of them as traitors, but if the long civil rights movement began as teachers sought equalization, fostered as it was by the NAACP, then they are at least partially responsible for the movement's existence at the time of Carmichael's rise to prominence. And their work continued. The Montgomery Bus Boycott, for example, was facilitated by the work of Mary Frances Fair Burks and Jo Ann Robinson, two female professors at Alabama State, the full fruition of women educators translating their work into activism. ${ }^{88}$

Back in the 1930s and 1940s, however, when those women's efforts at salary equalization were mediated through the black southern press, their role was diminished through paternalistic assumptions and reporting that played to the mores of the day, as, for the first time, a substantial southern black press corps covered a race rights fight led by women in a vocation dominated by women. The gendered mediation that would result created what Patricia Collins has described as "controlling images." Those images may not have reflected "the dominant group's interest in maintaining Black women's subordination," but there was in the coverage a clear sense of a woman's place. ${ }^{89}$ Such coverage not only diminished the roles of those women but ultimately diminished the presence of the teachers' salary equalization fight in the well-worn narrative of twentieth-century equal education fights, which were themselves the core of the pre- and post-World War II civil rights movement, as-surely to the relief of the Jacksonville Progressive News - men began to follow in their footsteps.

${ }^{87}$ Kirk, "The NAACP Campaign for Teachers' Salary Equalization," 532-34.

${ }^{88}$ Jacquelyn Dowd Hall, "The Long Civil Rights Movement and the Political Uses of the Past," Journal of American History 91, no. 4 (March 2005), 1233-263; see in particular 1253-254.

${ }^{89}$ Collins, Black Feminist Thought, 69, 72. 